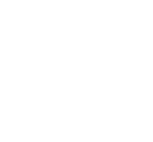

\title{
CRITICISMS TOWARD JAVANESE CULTURE IN PRAMOEDYA ANANTA TOER'S BUMI MANUSIA: AN ANALYSIS ON THE DOMINANT CULTURE OF THE PRIYAYI
}

\section{Yohanes Hartadi '}

\begin{abstract}
It is not an exaggeration if we say Java-with its people and its culture-dominates almost all aspects of the Republic of Indonesia. Many Javanese things are used and inituted by people other than Javanese. Pramoedya Ananta Toer, as a Javanese writer, sees the Javanese culture from another angle. He is able to notice the inappropriate Javanese concepts and practices. Bumi Manusia is a novel that reveals Pramoedva's criticisms loward Javanese culture.

Keywords: Javanese, culture, priyayi, mysticism
\end{abstract}

\section{INTRODUCTION}

'And he said, verily, I say unto you, no prophet is accepted in his own country.' 'These are Jesus' words which he said when he was in the synagogue to read the Talmud. The writer found that to certain extent an author is similar to a prophet. First, an (good) author should and will always bring revelation and enlightenment (aufklarung) to his readers. In composing a literary work, he cannot escape from reality, from civilization. Borrowing Pramoedya's words, reality which is found in the sphere of private and in the sphere of public is the 'upstream fact.' By grasping and analyzing the spirit of the streams coming down, the author alters it into 'downstream fact' which is

Yohanes Hartadi, SS. is a lecturer of the Faculty of Letters of Soegijapranata Catholic University, Semarang

2 This verse is taken from The New Testament. King James Version published by The Gideons International, chapter 4 verse 24 
46 Celt, Volume 1, Number 1, December 2001 : 45-62

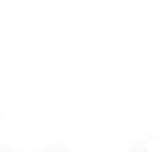

even not contained by historical fact. So be a literary work a thesis, a baby who commenced his own growth. He is just similar to new inventions in any field which bring the society a one-step progress. ${ }^{3}$ In this discussion we do not approach the works merely from the author and the text, the manner in which a text apparently points to this figure who is outside and precedes it as Michel Foucault suggested. ${ }^{4}$ We explore the novels within the cultural frame.

On the second place, an author in many cases is rejected by the society in which he lives. The rejection does not come by itself; rather, it is caused by the network of power under which every subject in the society subordinates. Let us look back to D.H. Lawrence the British novelist. His

3 'upstream fact' and 'downstream fact' are translations for 'Kenyataan hulu' and 'kenyataan hilir'. According to Alex Geoffrey Bardsley, historically, hulu and hilir carried similar connotations long before industrialization as forest products from back-country regions were transported to riverine and coastal entrepots for trade overseas (see Alexander Geoffrey Bandsley, 1996. A Political Subject: Changing Consciousness in Pramoedja Ananto Toer's Bumi Manusia and Anak Senua Bangsa. A Thesis. Faculty of Graduate School of Cornell University, p. 12). The terms also meen that to move 'upstream' is to retreat to the hitherland, lo become isolated and backward, to leave the progressive society of the trading ports, It is exemplified with Javanese literature which is dominated by wayang drama, oral as well as written, that tells of the Mahabharata and the Ramayana-the Javanese versions and their chewed-over wads, that continue to depend on the authority of Hindu culture. This dominant literature, without anyone being aware of it, glorifies the satria class or caste, while the classes or castes under it have no role whatsoever. The satria caste's main job is to kill its opponents. See: Pramoedya Ananta Toer. 1995, Literature, Censorship and the State: To What Extent is a Novel Dangerous? trans.Alex G. Bardsley. An esay to be delivered on September 4, 1995, in Manila. Published by Suara Independen, no.04/I, September 1995.

- Michel Foucault, the prominent postmodernist, set aside a socio-historical analysis of the author as an individual and the numerous questions that deserve attention: how the author was individualized in a culture such as ours; the status we have given the author, for instance, when we began our research into authenticity and attribution; the system of valorization in which he was included; or the moment when the stories of heroes gave way to an author's biography; the conditions that fostered the formulation of the fundamental critical category of 'the man and his work.' Read: Michel Foucault. 1991. What Is an Author in Rethinking Popular Culture. University of California Press. I991, P, 447 
novel, Lady Chatterley's Lover, was banned for the alleged cause of obscenity. In Russia, Boris Pasternak, the author of Doctor Zhivago was not allowed to receive the Nobel Prize for Literature in 1958 by the Soviet regime because the novel criticizes the regime and the revolution. In Indonesia, the rejection of authors is even harsher. Different from other countries, the subjects of this polemic consist of three groups: right authors, left authors and the state. Right authors are those signing the Cultural Manifesto. ${ }^{5} \mathrm{On}$ the opposite, left authors were those who were affiliated to Lekra a mass organization which was close to Indonesian Communist Party. Some of them were Putu Oka Sukanta, Sitor Situmorang and Pramoedya Ananta Toer. ${ }^{6}$

Pramoedya was detained for 14 years, 11 of them in Buru Island, a penal camp in the Maluku archipelago, some 850 miles east of Java. Jonathan Rosen (1999) called this island "South Seas Gulag." What is not fair with the imprisonment was that there was no prior charge nor trial. Until the present time, under the rule of the fifth President Megawati Soekarnoputri, the banning of his book is not yet abolished. It is ironical since Pramoedya's books are obligatory readers for university and high school

5. Manifes Kebudayaan was conceived as an anti-thesis for the movement and activities of Lekra (Lembaga Kebudayaan Rakyat/Institute of People's Culture) artists who were affilialed to PKI (Indonesian Communist Party). The Cultural Manifesto stated that culture was a struggle to improve the living condition of human being. The artists who signed the document further declared that they did not prioritized one cultural sector upon the other. All cultural sectors struggle altogether for the sake of culture based on its destiny. Then, what made it different was the ideology. While the Lekra artists uplifted Nasakom (Nationalism, Religion and Communism) and Manipol (Political Manifesto), the other group uplifted Pancasila consistently. Some of the right artists were H.B. Jassin , Taufiq Ismail, D.S. Moeljanto and Bur Rasuanto.

- Putu Oka Sukanta was jailed because of his affiliation to the mass organization. He revealed his terrible moment in jail into a novel Merajut Harkat (Knitting Human Dignity) Yogyakarta: Pustaka Pelajar and Jendela Budaya. 1999. About the violence sponsored by the state in dealing (abolishing) with people who were alleged to have been the members of PKI and its onderbow' post "1965 Affair' see: Budiawan, 2000. Tortured Body; Betrayed Heart. State Violence in an Indonesia Novel by an Ex-Political Prisoner of the '1965 Affair' in RENAI. Salatiga: Yayasan Percik. p. 34. Sitor Situmorang was also jailed by New Order regime because they, as he said, wanted to know what was in his brain. He was released from prison in 1978. Read: KOMPAS daily, 30 July 2001. P. 12. 


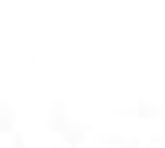

students in the neighboring Moslem country Malaysia. Despite the banning. the publication of his books is going on along with the spirit of reformation. Because of the long ideology engineering sponsored by the New Order regime, Pramoedya's name becomes a sort of tokoh haram or forbidden figure. An anti-VIP perhaps, who, though silenced, is the focus of noisy controversy. ${ }^{\text {He }} \mathrm{He}$ himself in keeping with the irresolution of his country's political present seems to be regarded as a literary lion, a national treasure and an enemy of the state. ${ }^{9}$

In this discussion, the writer will not glorify the author nor condemn the toppled New Order regime. The aim of this article is to explore the first novel of the Buru Quartet, Bumi Manusia. The Buru Quartet itself consists of four novels: Bumi Manusia, Anak Semua Bangsa, Jejak Langkah and Rumah Kaca. The Buru Quartet is probably Pramoedya's best known later work. ${ }^{10}$ It is one of those sprawling literary mansions, built of exotic materials, that display the mysteries of a foreign culture while magically containing

1. GULAG was a Russian abbreviation which meant the Main Administration of Camps. Under the GULAG prison, all subjects did forced labour. They were assigned to heavy, unskilled labour-cuiting timber, building roads, minirg coal, dredging for gold, and other similarly burdensome tasks. See Merle Fainsod. 1974. How Russia is Ruled. Harvard: Harvard University Press. Pramoedya told what the Buru prisoners felt in Nyanyi Sunyi Seorang Bisu or the English version The Mute's Soliloquy. The memoir mostly consist of his letters wrote to his children but were never sent. In a letter to her daughter he wrote about the ship that took him into exile on Buru and of the lines of a Negro spiritual that haunted him and gave him comfort during the journey. Changing keys abruptly, he shares with her his diet of "gutter rats, the moldy outgrowth on papaya trees and banana plants, and leeches, skewered on palm-leaf prior to eating." He describes how one of the most educated prisoners went about eating a lizard. breaking off the toe pads and swallowing it whole, adding, admiringly. From the description it not an exaggeration if Rossen names Buru Island some kind of GULAG. Review on The Mute's Soliloquy can be read in Jonathan Rossen. 1999. South Seas Gulag. An Indonesian Writer Recalls His Years on the Penal Island of Buru. New York: The New York Times Company.May 16, 1999. Neville and Blackburn uses the same term 'gulag' island of Buru in Loreen Neville and James Blackburn. Pramoedya: A Lismus Test of 'Reformasi. In Roving Insight, September-October 1999. Beth Hughes calls Buru Island equatorial gulag in Beth Hughes, 1999. Child of All Nations. in The San Fransisco Examiner. Sunday, May 16, 1999. 
rooms that seem designed with you in mind." Initially, the Buru Quartet was composed and told orally to his fellow prisoners in Buru. It was written there when he was granted permission to write. Then it was published after Jesuits brought the copies.

The resulting novels cemented Pramoedya's reputation as a storyteller, and Indonesia as a language capable of contributing to the international canon. These are the books to read to understand Indonesia. The Buru Quartet is a wonderful, stay-up-late, four volume read peopled by a huge cast of characters riding a plot as complex and twisted as modernday Indonesian politics. ${ }^{12}$ Bumi Manusia portrays the course of life of a young man who was born of and reared in an aristocrat family, Raden Mas Mingke. ${ }^{13}$ Minke's father is a bupati (regent) in the Regency of B. Teeuw (1996: 231) writes that a member of such an aristocratic family will be granted privileges provided that he adapt hemself to the double demand of the system. Firstly, he conducted under the norms of aristocratic culture and secondly, he subjected colonial's will who made use of Javanese aristocratic class to retain their power and integrity with minimum physical force. ${ }^{14}$ In Latin this kind of right is termed Forum Privilegiatum. "' However. Minke decides to choose the other way, the one with sad anid bitter experience. He protests and fights for his nation. Besides, Minke's life is inseparable from romance. Romantic

* Alex G. Bardsley. Pramoedya: Autodidact and Tokoh Haram. p.1. On line: http:/ /www.radix.net/bardsley/auto.ans

Jonathan. op.cit. p. 1.

to Alex. G. Bardsley. Pramoedya: Autodidact and Tokoh Haram. p.I. On line: hup://www,radix.nel/-bardsley/auto.ans

It Jonathan Rossen, op. cit.

12 Beth Huges. 1992. Child of All Nations. Indonesia's Greatest Writer Tours the World with New Memoir. Special to the Examiner, Sunday, May 16, 1999. P.2

13 A. Teeuw. Calls Minke a putra priyayi or anak priyayi tinggi. Read: Prof. Dr. A. Teeuw. 1996. Citra Manusia Indonesia dalam Karya Sastra Pramoedya Ananta Toer. Jakarta: PT. Dunia Pustaka Jaya. pp. 230-231.

14 A. Teeuw. Op. cit. p. 231

15. When he was about to be kidnapped by police agent to be carried to the Regent of B., Minke refused to follow the order by saying," I have Forum Privilegiatum." Forum Privilegiatum is a forum of equality to Europeans before the court for the native aristocrats (bangsawan) downward to Raden Mas or the equal and the regent's children and grandchildren. It can be found in Pramoedya Ananta Toer. 2000 Bumi Manusia. Jakarta: Hasta Mitra. p. 125 
50 Celt, Volume 1, Number 1, December $2001: 45.62$

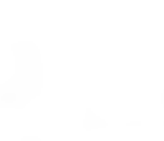

story starts with the introduction of character Annelies. They fall in love since then. This aspect makes the novel enjoyable both as a 'serious' and popular novels. ${ }^{16}$

Related to the protagonist's Minke, identity as a member of Javanese aristocrat family the writer is going to explore the narratives of both novel to find out the depiction of the author's on Javanese culture. Then, the author's criticisms toward the culture will be unearthed from the ground of narratives.

\section{NOTES ON JAVANESE CULTURE}

Prior to the elaboration on the Javanese culture, it is important that the writer limit the discussion on culture. What the writer would like to discuss here is the culture of Central Java and East Java, while West Java is excluded because of the rather far distinction and the setting of the story.

Java with an area of $132,000 \mathrm{sq}$. $\mathrm{km}$ is populated by more than 128 millions people, Java island is the densest of all other islands which are spread along the archipelago. With its vast human resources, Java becomes the powerhouse and dictator of Indonesia. ${ }^{17}$ Most Javanese work on farm or they work as labour farm. On the low land they cultivate rice while on the high land they plant palawija such as com, peanut, and mung bean. Javanese people have raised their standard of living which can be seen from their houses, especially in the village. Those who twenty years dwelt a bamboo (gedeg) house or wooden house now they dwell a permanent house.

\section{is A. Teeuw. Op. cif. p. 233}

17 Peter Turner. 1999. Java. Melbourne: Lonely Planet Publications. p. 11. Turner's opinion is probably true if we see it from the political economy. Most of the natural resources from Sumatra, Kalimantan, Sulawesi and Irian Jaya used to be carried to Java. As a result, a gap and resentment is created because the budget allotment for the development flowed to the provinces in Java island. With the enactment of Regional Autonomy the government of the provinces outside Java will receive more portion than that carried to the central government. The superiority of Java is also seen from the Presidency. The Republic of Indonesia has been led by five presidents four of whom are Javanese: Sukarno, Soeharto, Abdurrahman Wahid and the newly appointed President Megawati Sukarnoputri. 


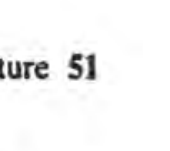

The Javanese people is divided into two social classes: wong cilik (common people) who are mostly farmers, small merchants and those living in cities with low income, and priyayi class which consists of government or private officers and intellectuals. Besides, there is the third class which still has exclusively high prestige namely ndara. "The last group will nor be discussed here since they have similar lifestyle to priyayi. The priyayi do not do blue collar job. They used to be very respected and some of them still try to raise their prestige and social status by getting married to a ndara family or priyayi family.

The word priyayi derives from para yayi that means the younger siblings of the king. Whether it is factual or not, the etymology is difficult to prove since the term priyayi is not found in the texts which were written before the $19^{\text {th }}$ century. ${ }^{19}$ There are many studies and papers which discuss priyayi. According to van Niel, priyayi as a social group around 1900 was an elite group namely anyone who somewhat possessed higher status than the common people, somewhat organized and guided the people. Administrators, goveroment officers and those who had good education and position were priyayi. Elite was not exclusively the descendants of the past kings. It is possible that they came from successful adventurers so that they could run a political power over some parts of Java and played the role of priyayi to the people. The titles which indicated self-pride such as Raden or Raden Mas was a title associated to a certain government administration but not associated to the royal family. However, it seems van Niel's definition is only effective in the Gupernemen region, the region which was directly included in the colonial government administration environment. He did not consider "erfelijkheidsbeginsel" (the principle of descent) in the policy of colonial government office. The principle of descent became one of the conditions for a person to be appointed government officer. ${ }^{20}$

Palmier said that priyayi is the children of bupati. He distinguishes priyayi into priyayi luhur and priyayi kecil. There is a vague limitation between the two priyayis. Priyayi luhur is the genuine priyayi which can be

\footnotetext{
1x Franz Magnis-Suseno. 1999 Etika Jawa. Jakarta: Penerbit PT. Gramedia Pustaka Utama. p 12.

Iv Sartono Kartodirjo, et. al. 1987 Perkembangan Peradaban Priyayi. Yogyakarta: Gadjah Mada University Press. p. 3

Ibid. pp. 4-5.
} 


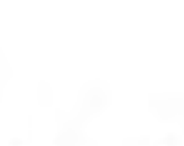

seen from the position of the father, the family descendant of the mother and the family descendant of the wife. Priyayi kecil is priyayi due to his position in the government administration. The other differences can be seen from their homes, dressing style, and lifestyle. ${ }^{21}$

Heather Sutherland does not consider the family descent as a matter. He concerns with priyayi as a social group which monopolized the positions in the inland govermment administration so that the government can be termed as priyayi-government. Toward common people priyayi became the heir of traditional authority which was feudal. ${ }^{22}$ Savitri Scherer certainly states that priyayi is the officers of Dutch Colonial Government. Because of the development of Western education in pace with the increasing colonial need at the end of $19^{\text {th }}$ century, and the beginning of $20^{\text {th }}$ century, priyayi is divided into two groups. First, bureaucrat priyayi, namely priyayi which hold the positions of pangrehpraja (civil service) and continue the tradition of the older priyayi. Second, professional priyayi, namely priyayi who hold the government positions which require special knowledge and skill, ${ }^{23}$

Priyayi has their own spiritual life. Compared with wong cilik who observed Islam in nearly all aspects of life, the former live their life in the Javanese traditions before the coming of Islam. This practice of spiritualism is called kejawen. Many of them are the followers of paguyuban (associations), those who search for the fulfillment of human life through the practice of asceticism, meditation, and misticism. ${ }^{24}$ Kejawen or Javanism is not a religious category. It refers to and ethic and lifestyle inspired by Javanese thought. Javanism is suitably practiced by the old keraton (palace) elite or elite who are government-and-their descendants oriented-called priyayi ${ }^{25}$ The practice of Javanism-also called kebatinan-is an effort to communicate with highest reality; as a branch of knowledge it studies human being's space in the world and universe. It is based on the belief in the true

\footnotetext{
21 Ibid. p. 7

22 Ibid p. 8

23 lbid. p. 8
}

26 Franz Magnis-Suseno, op, cit. p.13. However, the term kejawen should not be confused with kejawen for geographical meaning. Kejawen covers Yogyakarta and Surakarta which are the benchmarks of Javanese culture. They are rich of artistic heritage and refinement of keraton (royal palace).

25 Niels Mulder.2001 Mistisisme Jawa. Ideologi di Indonesia. Yogyakarta: Penerbit LKiS , pp, 4-5 
oneness of all existence. ${ }^{26}$ In many cases, under the guidance of a guru, selfenlightenment is sought through typically priyayi pursuits of self-denial, restraint, humility, and meditation. ${ }^{27}$

Other factor which distinguish priyayi and wong cilik is the language they use. Traditional Javanese society is hierarchical, and great importance is placed on politeness, humility and deference to superiors. ${ }^{28}$ The hierarchy is also shown in Javanese. We can find the reason to this by tracing back the history of Java. From the period of Panembahan Senapati onward, Pajang was under the authority of Mataram. Because of the dimming power, rulers desired to exhibit their glory, greatness and superiority, not only to their subjects but also to their conquered regents. For this purpose, it was necessary to create and develop a social distance between the ruler and his subjects. A good means to create this social distance was through the creation and cultivation of royal culture and art, ant this included the introduction and development of different levels of speech. ${ }^{20}$ They are krama, madya and ngoko ${ }^{30}$.

In its development, Javanese speech levels have more practical functions. G. Moedjanto (1993:pp.69-72) writes four functions of the Javanese speech level. First, one of them is organizing the rules of social relationship. In this case, the level functions as a norm of social relationship.
$2 n$ Ibid. p. 40
27 Peter Turner. op.cit. p. 64
23. Ibid. p. 405.
24 G. Moedjanto. 1993. The Concept of Power in Javanese Culture. Yogyakarta: Gadjah Mada University Press. p. 75.
w Ibid.pp. 55-56. Supomo Pudjosudarmo, as quoted in this book, divided krama into mudha-krama (young krama), kramantara (middle krama), and wredha- krama (old krama); madya into madya-krama (high-madya), madyantara (middle madya) and madya-ngoko (low madya); and ngoko into basa-antya (high ngoko). anrya-basa (middle ngoko) and ngoko-lugu (low ngoko or simple ngoko). The ngoko level is used by a person speaking to another: who is of younger age; who is seen as younger from the point of view of family relationship; whose rank of nobility is lower; who is known intimately by the speaker; and who becomes the speaker's opponent or enemy. The krama level is used basically in the opposite of the use the ngoko. The simpler division of Javanese is mentioned by Purbacaraka: krama and ngoko. While according to Purwadarminta Javanese is divided into three level: krama, madya which is divided further into madya- krama and madya-ngoko and ngoko. The example for use read: lbid. pp. 57-58. 
54 Celt, Volume 1, Number I. December 2001 : 45-62

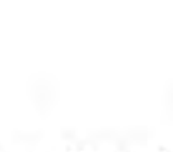

Thus, one has to speak in a certain way to others; one is not allowed to speak in any way one likes. Second, closely related to this is its function as an unggah-ungguh (a norm of politeness). This may have begun among subordinates who were so anxious to show their politeness. On the other hand, this polite manner also came to be expected by their superior. Third, Javanese speech levels also function as a medium to express both honour and intimacy, in accordance with the meaning of the two basic levels. ${ }^{31}$

When we talk about priyayi society, we should also talk about the position of woman because most of the definitions of priyayi as we read before rely on the position of man in his job. In general, priyayi society has a patriarchal system which poses the dominant role of man whereas woman only plays trivial role. It is a fact that in a patriarchal society man is dominant in many aspects of life such as bio-social, politic, socio-cultural and religion. In a household environment, man is the head of the family who possesses authority to make a decision, make a living; his position determines the family status, descendant, and leads the relatives. The role of woman is normally create education for the children and all household management. It is not surprising when woman's role is more bound to the family and household environment so that there is a term used by husbands "kanca wingking" (friend at the back) .32Female children are also educated to do their job as a wife as well as family mother. At the age of pre-emancipation, they used to live in a "cage" within the family environment. ${ }^{33}$

\section{ANALYSIS}

Considering the year of the process of writing and publication, Bumi Manusia is a postmodernist work. We have discussed previously the Foucauldian theory on literature which lets the reader view a literary work as an independent entity. The debates about the nature and status of narrative representation in historical discourse coincide and are inextricably intertwined with challenges offered by historiographic metafiction. Yet we have seen that postmodern fiction is typically denounced as dehistoricised, if not ahistorical, especially by Marxist critics. ${ }^{34}$

"Ibid.pp. 69-72

32 Sartono Kartodirjo. op. cit.p. 192

3) Ibid. p. 192

44 Linda Hutcheon. 1999. Telling Stories: Fiction and History. in Modernism/ Postmodernism. London: Longman.1999. p. 238. 
Teeuw (1997: 230) says that The Buru Quartet, which was published in 1980s, had been planned by the author long before. When Pramoedya was getting more aware that "the people must know their history", especially since 1956, he started to do a broad historical research on the age of the beginning of Indonesian nationalism. In the research he found Tirto Adhi Soerjo, nationalist of the first generation, which did not catch attention in the national historiography. This character inspired Pramoedya to write the historical tetralogy romance. ${ }^{35} \mathrm{We}$ may say that postmodemist discourse on literature is still arguable since theorists have their own arguments on how a work should be studied. Let us depart from the argument and below is the discussion on the main point, criticisms toward Javanese culture in Bumi Manusia.

\section{THE TRADITION OF PRIYAYI-KAWULA}

Minke is the speaker in Bumi Manusia. As a Javanese with Western education, Minke becomes conscious of the surrounding condition. He is becoming more critical with the system and even with his own culture, Javanese in which he was brought up. When Minke had visited Annelies and Nyai Ontosoroh in Wonokromo for the first time, a female servant served them. Minke was surprised by her altitude to her mistresses.

A female servant serves chocolate milk and biscuits. And she does not crawl just like with Native master. Even she glances at me as if she showed me her surprise feeling. This is not found with Native master: she has to keep her chin down and down. What a beautiful world will be without crawling in front of others. (p. 20)

This incident stimulates Minke's modern thought to be critical. He dares compare his own culture and the Westem culture. More than that he judges which attitude is better. On other occasion Minke not only witnesses other person crawling before priyayi but he himself crawls. Minke is summoned by the Bupati of B. In pendopo, he comes to see the unknown regent. As a student of H.B.S. Minke feels humiliated to crawl and to do all courtesy. 


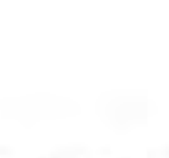

So I'm to be brought before the Bupati of B. God! On what account? And I, an H.B.S. student, must I crawl before him and raise a sembah? ?6 $^{36}$ each period of every sentence I utter, for someone I do not know at all? While walking towards the hall, already lit by four lamps, I felt like I would cry. What use is studying the arts and sciences of Europe, of socializing with Europeans, if in the end must still crawl, slithering like a snail, and make obeisance to some petty king who is probably illiterate on top of it. God!, god! To face a bupati is the same as preparing to take humiliation without being allowed to defend oneselp"...(pp. 130-131)

Minke is really annoyed by what he has to do. He tells himself that he swears in more than three languages while crawling 10 metres distance. Nevertheless, Minke's anger subsides when he finds out that the bupati of $B$, is in fact his own father. He regrets his indifferent action of not replying his father's and his mother's letters. He surnenders under his father's whip. Although he feels humiliated and tortured by his father's words, he keeps his obeisance by saying nothing. However, he makes a resistance by calling his father "blood of Javanese kings. "The term is true in its meaning, because his father is a king in his regency but at once Minke also shows his father's traditional mind vis-à-vis his modern rationality. In fact, a bupati places higher position than a resident assistant does due to his knowledge on place, birth, his influence on people, his income in the form of currency, and his

3. Sembah is a gesture used by Javanese and other ethnic in Indonesia to show obeisance.

37 This English version is bortowed from Alex. Geoffrey Bardsley. 1996. A Political Subject: Changing Consciousness in Pramoedya Ananta Toer's Bumi Manusia and Anak Semua Bangsa. A Thesis. Faculty of the Graduate School of Cornell University. p. 25.Minke calls the bupati petty king because he rules only a region not a real kingdom. The Dutch made it their policy in Java to proceed with as little interference as possible. The status of the bupati was deliberately maintained in order that they could become the central administrative tool through which the Dutch extracted profits. They reasoned that the volkshoofd (traditional chief) would be able to maintain authority far more effectively than could be expected through any structural changes to the system. When the activities of the V.O.C. (the Dutch East India Company) was taken over by the Dutch government in 1800 , the general policy toward the regents was maintained. In maintaining their authority, the regents would remain loyal to the Dutch government while the populace would remain loyal to the regent. Read: John M. Brownlee. op. cit. p. 4. 


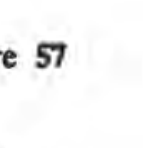

akin lifestyle. Whenever a European takes a trip, several officials go along, sufficient to give some information in the inspection trip-while bupati is followed by hundred of people. A European lives as common people, yet a bupati lives as a king. ${ }^{38}$

Still in the same house, Minke meets his brother who reads his diary stealthily. Minke catches him reading it and he snatches it from his brother's hand instantly. Once again traditional mind is against modern rationality. Minke is offended by his brother's action of minding other's business and his brother feels offended with the way he snatches the book. Their way of thinking do not make a compromise here. To release his disappointment, his brother says that Minke is not a Javanese anymore.

You are not a Javanese anymore"

What's my being a Javanese for if my rights are to be violated? Don't you know that such note is very private? Haven't your teacher taught you ethics and personal rights? (p.139)

Minke's mother thinks in the same way as his brother, She says that he is not a Javanese anymore, he has tumed into a brown Dutch. The priciple of kawula-gusti is also effective in a Javanese aristocratic family. The older should be respected regandless of his mistake. This is what Minke does not do anymore. His mother says that this is a sign proving that Minke is not a Javanese anymore.

That is a sign you are not Javanese anymore, does not notice who more deserved honour is, who has higher authority" (p. 141)

\section{THE USE OF JAVANESE}

On other occasion, Minke's mother comes to Wonokromo to celebrate her son's wedding to Annelies, Nyai Ontosoroh's daughter. The night before the wedding, Minke meets his mother asks him where his tembang (metres) which can be sung in the night she is longing for him are. Minke answers that he cannot write Javanese. Minke is considered 'not yet Javanese' because he writes in Dutch while his ancestors, the kings of Java, wrote in Javanese. His mother suggests that Minke write in Javanese.

If you are still Javanese, you will always be able to write Javanese"

Your ancestors, the kings of Java, all wrote in Javanese. Are you ashamed of being a Javanese? Are you ashamed of being not a Dutch? (Bumi Manusia p. 347)

- Multatuli. 1991. Max Havelaar. Jakarta: Penerbit Djambatan. 


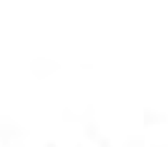

Bumi Manusia does not give the answer to Minke's reason why he does not use Javanese as medium to convey his thought and opinions. The answer to this is given in the next novel of the quartet, Anak Semua Bangsa. ${ }^{34}$

\section{JAVANESE SPIRITUALISM}

Minke's mother-in-law, Nyai Ontosoroh, used to be the daughter of a privayi family. His father, Sastrotomo, was a secretary of sugar factory. Villagers paid him a respect as he was the only one literate. He was not yet satisfied with the job although the job was quite high for the native (inlander). He wanted to get the post of cashier in the factory. For that reason he worked more and more diligently, yet his rank was not lifted. He worked hard for more than ten years. He had taken any way he could, including going to the dukun (shrink), saying spells, memutih fasting, and fasted every Monday and Thursday. ${ }^{40}$

So were taken any way: visiting the shrink, saying spells, memuth fasting, fasting every Monday and Thursday. It didn't work out" (Bumi Manusia p. 81)

34 The same criticism comes from his fellow Dutch journalist, Kommer, who questions him whether he is already Tair to write to Dutch-speaking readers while he owes them nothing at all. From that moment, Minke starts thinking about writing in other language than Dutch. He chooses Malay to learn.

"I am about to learn to write Malay, I answer. Nevertheless, it cannot be mastered in a day" (p. 206)

Jean Marais, a fellow French painter, throws similar criticism to Minke. Minke once said that he was an admirer of French Revolution. Jean Marais sees an ambivalence in Minke's attitude. On one hand, he admits that he follows the spirit and motto of French Revolution. On the other hand, he enjoys his aristocratic privileges. Marais makes an example: Minke is offended when a peasant talks to him in ngoko. The French painter says that Minke still cannot free himself from the ease that he gets from his ancestors. Minke is cunning. Minke does not deny this. He admits that Marais is right.

I have to admit that I cannot free myself from the ease of heritage. Listening someone talking ngoko to me, I feel that my rights are confiscated. On the contrary, listening someone talking krama to me, I feel being selected human being, dwells on top, god in human body and the ease of the heritage comforts me. (Anak Semua Bangsa p. 207)

4. Memutih fasting is a Javanese spiritual practice in which a person eats only rice. 
Because everything does not work, Sastrotomo let his daughter, Sanikem, to be Mr. Big's (Mr. Herman Mellema) concubine in the exchange with the position. In fact Sastrotomo got the position.

Indeed, mysticisms practices such as tirakat did not work. As the solution to the problem is not the point, it will not be discussed here. Pramoedya tried to say his extreme criticisms toward the practice of Javanese spiritualism through the character of Sastrotomo Pramoedya frankly says that such practices are useless, bring no avail. There is nothing wrong with the actual people of Java, but spare us the 'Javanese-ism.' There is a romaticizing of Javanese mysticism. Let's be rational instead. ${ }^{41}$

Pramoedya's weakness in giving the criticizm is that he does not try to give an explanation why the mysticism is of no use. According to Mulder (2001:43-44), such practice as Sastrotomo's is a practice of tapa and meditation which can be used to achieve goals entirely worldly and magical which may harm others, certainly it is led by egoistic molive, or pamrih. ${ }^{42}$

\section{RATU ADIL}

When people practice mysticism on its path and observe their raligion diligently, there will be a harmony between people and the world materially and morally. Javanese people always long for this condition. Human being and the cosmic structure are inter-related, they try to create a union and equilibrium. Mulder (2001:24) names this condition as golden age, when just kings rule and their people live in prosperity. Nevertheless, when the ruling elite, are led by their worldly passion, there will come injustice, and disorder, poverty and hardship. This age is called zaman edan (mad age). When the condition comes, Javanese people long for the coming of Ratu Adil or Just King who will restore the harmony. Recently, this such messianic hope is associated to Semar, the Javanese guiding spirit, who is the patron of Pandawa in Mahabharata epic. ${ }^{43}$

Pramoedya does not oppose the idea of Ratu Adil in Javanese mysticism. He only criticizes the way people hope the coming of him (or her).

4 Terry Mc.Carthy. 1998. Novel Cause. Time Asia, April 20, 1998 Vol.151, No. 15 p.3

42 Niels Mulder. Ibid. p. 44

43) Ibid. p. 24 
60 Celt, Volume 1, Number I, December $2001: 45-62$

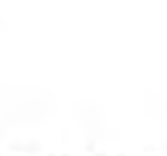

Gamelan sings more about a country which longs for the coming of a Messiahlonging, not searching and not giving birth to. Papa more said: if in the next ears a Javanese is still the same, without a change, it is a sign that this nation still does not have its Messiah. (Bumi Manusia, p. 214)

Laksono (1990:53) exemplifies Pangeran (Prince) Diponegoro as a Ratu Adil when he led his people to fight against the Dutch during what is called Java War (1825-1830). ${ }^{4}$ In seeing the practice of Javanese mysticism, Pramoedya highlights the real action rather than doing irrational ritual and belief. It is not necessary for Javanese people to long for a Messiah. The most important thing is give birth to or search for him. How can it be realized? It can be done by learning modern thought and release oneself from superstition. Mysticism should not be deleted from Javanese society, rather is should be accompanied by real action to realize the hope.

\section{CONCLUSION}

Culture is a precious heritage that should be kept and then again passed on to the next generation. However, people should be more aware of the confining aspect of the culture which bring about no progress for humanity, As age advances, hopefully the condition of humanity gets improved. It can be realized when people are more critical to their culture and customs which so far are taken for granted.

To share the progressive and critical ideas, a medium is needed. Pramoedya, as an author, provides the medium: novel Bumi Manusia. Through this two novel, Pramoedya try to evaluate, and re-evaluate the condition of human being as he sees it. In Javanese culture, there are still many thing to be evaluated. They are the essence of the relation of priyayikawula; the impractical use of Javanese levels; and Javanese mysticism which emphasizes only on the spiritual practices which are not accompanied by action. Just like a pendulum which sways from the left to the right and then arrives in the middle, culture always changes because human being, as the creator, the actor and the keeper, try to find the most suitable form of it. So culture passes the dialectical change and will always does with the final goal is improve the degree of humanity.

4 P.M. Laksono. 1990. Tradition in Javanese Social Structure Kingdom and Couneryside. Yogyakarta: Gadjah Mada University Press. 


\section{BIBLIOGRAPHY}

Annonymous. 1998. Dissident Writing in Indonesia. in The Economist, July $18,1998$.

Bardsley, Alex. G, 1996. A Political Subject: Changing Consciousness in Pramoedya Ananta Toer's Bumi Manusia and Anak Semua Bangsa. A Thesis. Faculty of the Graduate School of Comell University.

Bardsley, Alex G. Pramoedya: Autodidact and Tokoh Haram. On line: hup:l Lwww,radix.ne// bardsley/auto,ans

Brownlee, John M. Colonial Knowledge and Indigenous Power in the Dutch East Indies. in Exploration in Southeast Asian Studies, SEASSA, volume 2, Number 1: Spring 1998.

Budiawan. 2000. Tortured Body, Betrayed Heart. State Violence in Indonesian Novel by an Ex.Political Prisoner of the "I965 Affair" Salatiga: Yayasan Percik: RENAI Journal Tahun 1, Nomor 1, Musim Penghujan Oktober 2000-Maret 2001.

Fainsod, Merle. 1974. How Russia is Ruled. Harvard: Harvard University Press

Foucault, Michel. 1991. What is an Author? in Rethinking Popular Culture. Los Angeles: University of Califormia Press.

GoGwilt, Chris. 1996. Pramoedya's Fiction and History: an Interview with Indonesian Novelist Pramoedya Ananta Toer, in The Yale Joumal of Criticism 9.1, 1996.

Hutcheon, Linda. 1999. Telling Stories: Fiction and History in Modernism/ Postmodernism. London: Longman.

Jensen, Geeta Sharma. 1999. Prison Years Haven ' Slowed Writer. Milwaukee Journal Sentinel. May 16, 1999.

Laksono, P.M. 1990. Tradition in Javanese Social Structure Kingdom and Countryside. Yogyakarta: Gadjah Mada University Press.

Mandal, Sumit. 1996.Pramoedya and Independence. New Strait Times August 21, 1996.

Mc.Carty, Terry, 1998. Novel Cause. Time Asia, April 20, 1998, Vol 151, No. 15

Moedjanto, G. 1993. The Concept of Power in Javanese Culture. Yogyakarta: Gadjah Mada University Press. 
62 Celit, Volume I, Number I, December 2001 : 45-62

Mulder, Niels. 2001. Mistisisme Jawa. Ideologi di Indonesia. Yogyakarta: Penerbit LkiS.

Multatuli. 1991. Max Havelaar. Jakarta: Penerbit Djambatan.

Neville, Loreen and James Blackburn.1999, Pramoedya: A Litmus Test of 'Reformasi'. in Roving Insight, September-October 1999.

Proffitt, Steve. 1999. Escaping Indonesia's Iron Fist in Fiction, but not in Life. Los Angeles: The Los Angeles Times, June 6, 1999.

Ragan, David Paul. 1998. Pramoedya Ananta Toer: Meeting a Dissident Writer. in Humanities, March/April 1998.

Rosen, Jonathan. 1999. South Seas Gulag. An Indonesian Writer Recalls His Years on the Penal Island of Buru. New York: The New York Times, May 16, 1999.

Suseno, Franz Magnis. 1999. Etika Jawa. Jakarta: PT Gramedia Pustaka Utama.

Teeuw, A. 1997. Citra Manusia Indonesia dalan Karya Sastra Pramoedya Ananta Toer: Jakarta: PT Dunia Pustaka Jaya.

Templer, Robert. Pramoedya. in Prospect Magazine. On line: hutp:ll www.radix.net/-hardsley/templer.htm

The New Testament/Perjanjian Baru. 1991. Jakarta: Lembaga Alkitab Indonesia and The Gideons International

Toer, Pramoedya Ananta. 2000. Anak Semua Bangsa. Jakarta: Hasta Mitra. 2000. Bumi Manusia. Jakarta: Hasta Mitra.

1995.I Have Closed Book on Power. trans. Alex G. Bardsley. in Suara Independen, No. 3/I August 1995.

1999. Literature, Censorship and the State: To What Extent Is a Novel Dangerous. trans. Alex G. Bardsley. An Essay Written to be delivered on September 4, 1999 in Manila on request of Ramon Magsaysay Award Foundation.

1992

1992. Maaf atas Nama Pengalaman. in Progres, no. 2.

Tumer, Peter. 1999. Java. Melboume: Lonely Planets Publication. 